\title{
A dialética em questão: considerações teórico-metodológicas sobre a historiografia contemporânea ${ }^{1}$
}

Carlos Zacarias F. de Sena Júnior ${ }^{2}$

UNEB/Alagoinhas

\section{RESUMO}

Este artigo analisa os aspectos teóricometodológicos da historiografia contemporânea, tendo a questão da dialética como elemento central. A partir de um texto marcante da historiadora Emília Viotti da Costa, "A dialética invertida", que propunha uma síntese entre as correntes estruturalistas e pós-modernas, busco demonstrar que uma determinada tradição marxista nunca deixou de promover as sínteses que são essenciais ao método dialético.

Palavras-chave: Historiografia; Dialética; Marxismo.

\section{ABSTRACT}

This article analyses the theoretical and methodological aspects of contemporary historiography, focusing on dialectics as its major issue. Departing from Emília Viotti's outstanding text "A dialética invertida", in which a synthesis between structuralist and post-modern perspectives is proposed, as its point of departure, I argue that a certain marxist tradition have never failed in putting into practice the essential synthesis of the dialectical method.

Keywords: Historiography; Dialetics; Marxism.

Em 1994 a historiadora Emília Viotti da Costa publicou, na Revista Brasileira de História, um importante texto no qual procurava fazer um balanço da produção historiográfica da segunda metade do século XX. O artigo, que veio a público com o provocativo título de "A dialética invertida: 1960-1990", dava continuidade a um projeto iniciado poucos anos antes, quando Viotti se dedicara a discutir as tendências da história social do trabalho, num texto publicado em 1990, no Boletim Informativo e Bibliográfico de Ciências Sociais (BIB). ${ }^{3}$ Neste último caso, no artigo intitulado "Estrutura versus experiência: novas tendências na história do movimento operário e das classes trabalhadoras na América Latina: o que se perde e o que se ganha", a historiadora propunha-se a discutir os caminhos da historiografia sobre os "mundos do trabalho”, ultimamente bastante influenciada pela chamada história social inglesa 
e pelos estudos culturais franceses e americanos. Sua argumentação girava em torno das desvantagens e vantagens ("o que se perde e o que se ganha") de se aderir a uma tal metodologia, e sua questão referia-se à irrupção dessa nova historiografia e aos desafios que esta lançava aos historiadores, ainda muito ligados às posturas ditas tradicionais. Pelo desafio dessa nova historiografia, ainda segundo Viotti, conclamava-se ao abandono das noções "objetivistas" e "essencialistas" de uma tal "história tradicional", simbolizadas na metáfora "base" (ou infra-estrutura) e "superestrutura". Este tipo de história deveria dar lugar ao estudo das "subjetividades", sendo a cultura e a experiência os lugares privilegiados dessa nova abordagem. Tal postura teria, ainda, procurado deslocar o foco, dos grandes sujeitos e personalidades da história para as individualidades e personagens anônimas, ou, como preferiam alguns, para "uma história vista de baixo”. A conclusão de Emília Viotti, no texto de 1990, era pela possibilidade e pela necessidade de uma síntese entre os novos estudos e as abordagens ditas tradicionais, na medida em que tanto os novos historiadores não poderiam prescindir das "estruturas" na sua análise da cultura e da experiência, quanto os historiadores tradicionais não poderiam negar que, para além das grades da "necessidade" e das pressões objetivas, havia também a margem de "liberdade" em que homens e mulheres faziam a história. ${ }^{4}$

Os ventos que sopravam na historiografia do trabalho, campo predominantemente ocupado pelas tendências marxistas e engajadas, também sopravam em outros cantos da história, de modo que Emília Viotti entendeu a necessidade de estender sua reflexão para a historiografia como um todo. Assim, sua intenção no texto seguinte "A dialética invertida", de 1994, era já mais ambiciosa, isto porque a historiadora ampliava o leque das suas considerações que passavam a abarcar não apenas um nicho específico dos estudos históricos, mas a historiografia como um todo. Sua nova reflexão iria se confrontar tanto com as correntes e posturas metodológicas que pretendiam erigir um novo paradigma por sobre os escombros da historiografia anterior (cartesiana, estruturalista, marxista), quanto com as correntes que se apegavam tenazmente às concepções tradicionais.

Nesse sentido, a polêmica em torno dos “problemas", das “abordagens" e dos "objetos" que opunham correntes metodológicas supostamente antagônicas, para Emília Viotti estava, também, relacionada às mudanças ocorridas no mundo naqueles anos. Portanto, o fato de a balança historiográfica pender para as "novas metodologias" que passaram a estabelecer um poderoso campo de atração para muitos estudos acadêmicos, realizados no mundo europeu e americano, principalmente, se representava um avanço em relação a 
inúmeros aspectos das posturas anteriores, trazia, também, inúmeras dificuldades. Na medida em que se tratava das chamadas correntes "pós-modernas", que na historiografia brasileira davam apenas os primeiros, mas decisivos, passos no sentido de se constituírem em importantes referências, seria necessário refletir sobre os contextos em que se havia criado o novo paradigma, para aferir a sua aplicabilidade à realidade brasileira.

\section{A QUESTÃO: A DIALÉTICA INVERTIDA?}

Não está em questão aqui a retomada de toda a argumentação de Emília Viotti, senão apenas das motivações que a levaram a produzir seu artigo. Estas serão, também, objetos de reflexão neste texto, considerando o acordo que tenho com boa parte das proposições da historiadora e a relevância dos problemas que levantou para uma análise da historiografia recente. Antes de passar às minhas próprias considerações que girarão em torno dos aspectos teórico-metodológicos da historiografia contemporânea e da possibilidade/impossibilidade ou mesmo da necessidade de síntese proposta pela historiadora, será importante dar conhecimento ao leitor deste artigo da idéia central de Emília Viotti, que, como foi dito, dará o mote para seguirmos adiante.

Resgatamos, então, a interessante "imagem" evocada pela autora na abertura do seu texto: "Mai 68, on a refait le monde. Mai 86, on refait la cuisine". Sobre o "dístico bem humorado" que nos apresenta a historiadora, aparecido no jornal francês Le Monde em maio de 1986, Viotti informa que foi reproduzido na capa de um volume, de 1987, da Radical History Review americana. O sentido da reprodução da idéia do jornal francês na revista americana, segundo a autora, era fruto das preocupações de uma parcela dos historiadores quanto aos deslocamentos dos estudos históricos promovidos pelas novas abordagens que estariam abandonando "o projeto de construção de uma sociedade mais humana”. Da associação de um grupo de historiadores a práticas novas e questionadoras das tradicionais, e da reação destes últimos ao abandono de projetos coletivos, a historiadora concluiu que havia uma divisão dos historiadores em dois grupos distintos: o primeiro seria o daqueles que viam com "suspeita" e "reserva" os novos estudos, "continuando a reproduzir as posturas e abordagens estruturalistas da década de 60"; e o segundo seria formado pelos que se dedicariam a demolir as posturas ditas tradicionais, "convencidos da validade do novo, simplesmente porque é novo, sem se preocuparem em examinar as possíveis limitações e implicações das novas 
abordagens". Para Emília Viotti, ambas as posições estariam equivocadas: uma porque não teria incorporado as mudanças das últimas décadas, apegando-se a esquemas ultrapassados, e outra porque simplesmente preferiria "inverter" os postulados da historiografia dos anos 60, "em vez de integrá-los numa síntese mais rica", com isso incorrendo no risco de estar recriando uma história "tradicional". Nesse texto, como no anterior sobre a história do trabalho, Emília Viotti propõe também uma síntese entre as novas abordagens e as abordagens tradicionais. Entretanto, antes de chegar a concluir pela necessidade de síntese, a autora faz referência à década de 1950, quando teriam surgido as primeiras fissuras ("sinais de tensões") em torno dos modelos que agora se pretendiam enterrar. ${ }^{6}$

Para a historiadora, teria sido em fins dos anos 50 que os filósofos franceses Jean-Paul Sartre e Merleau-Ponty, de pontos de vista diferentes, teriam exposto as primeiras perplexidades e dúvidas que desembocariam no "impasse teórico" dos anos posteriores. Seguindo o mesmo caminho, mas não necessariamente inspirados nas questões de Sartre e Ponty, Viotti aponta para os trabalhos das décadas seguintes, em especial as críticas dos marxistas ingleses, o historiador Edward Thompson e o crítico literário Raymond Williams, que também se levantaram contra os limites dos "mecanicismos e dos reducionismos economicistas" da historiografia do seu tempo, principalmente da historiografia inspirada no marxismo estruturalista de Althusser. Segundo Viotti, o que nascera como uma crítica necessária a uma historiografia demasiadamente apegada aos fatores objetivos, terminou por se tornar, "contrariamente às intenções daqueles autores, numa total inversão da dialética". E a que se atribuiria essa inversão? Um dos problemas diria respeito a "excessiva ênfase no discurso", que teria promovido a "reificação da linguagem", corolário do apelo do filósofo Jacques Derrida quando afirmava a necessidade de se "interpretar a interpretação mais do que interpretar as coisas". ${ }^{8}$ Além disso, teriam sido abandonadas as críticas "perspicazes" de Sartre que "propunha-se a recuperar o homem no interior do marxismo", optando-se por Nietzsche e seu esteticismo. ${ }^{9}$ Por fim, a "nova" historiografia teria, de certa forma, refletido as transformações pelas quais passava a sociedade contemporânea, especialmente as sociedades européia e americana, e caberia aos historiadores latino-americanos se indagarem sobre a sua validade dentro de outros contextos. ${ }^{10}$ A conclusão de Emília Viotti é a de que estaríamos, possivelmente, vivendo um novo período da história, período este que seria de crise do capitalismo e, por conseguinte, momento propício a "uma nova síntese que evite todas as formas de reducionismo e reificação". ${ }^{11}$ 
Lá se vão dez anos desde que Emília Viotti publicou o seu texto. Talvez não seja o momento nem o espaço adequados para uma revisão do que foi dito pela historiadora. Na verdade o que vimos foi um aprofundamento dos problemas levantados por ela (veja-se o caso da extensão da crise do capitalismo com a economia americana próxima a uma recessão, e da eclosão de guerras de conteúdo imperialista que alguns supunham enterradas). Também no campo teórico-metodológico, embora algumas sínteses já tenham sido feitas e muitas outras estejam ainda em curso, o que vemos é a oposição se cristalizando entre as correntes de abordagens diversas que dominam este ou aquele programa de pós-graduação pelo Brasil afora. No meio do tiroteio epistemológico, assistimos atônitos ao marxismo como a principal herança a ser abandonada, quando não o principal inimigo a ser abatido.

Portanto, o que pretendo aqui é retomar e, de certa forma, aprofundar o argumento central de Emília Viotti da Costa, trazendo à luz novos elementos para indicar que se há a possibilidade de alguma síntese, esta deveria começar pela identificação precisa da herança a que se quer renunciar. Com essa intenção, promoverei um recuo ao início do século XX, por vezes até ao próprio Marx, para tentar demonstrar que as críticas feitas recentemente ao materialismo histórico pressupõem muito mais o abandono da dialética como concepção da história, do que a sua inversão, e que as possibilidades de síntese não se apresentam para todos os campos da historiografia igualmente.

Assim, busco identificar nas críticas dos "outros marxismos”, não apenas as de Sartre e Thompson, mas também as de Trotsky e Gramsci, os fundamentos de uma historiografia antideterminista e antidogmática que trafega sem problemas no campo das "liberdades" e "subjetividades", sem abandonar "simplesmente" os postulados da historiografia tradicional. Por fim, abordarei um campo metodológico que vem recentemente promovendo algumas sínteses importantes, do tipo das citadas por Viotti, cujos autores se dedicam a pesquisar a história social e política do Brasil a partir das condições reais de existência em que os homens fizeram a história. De outro modo, não seria necessariamente o caso de uma "inversão da dialética", mas do seu abandono puro e simples, através da transfiguração da sua forma e conteúdo.

É verdade que a autora não vai adiante na sua definição da dialética, entretanto a própria forma de encadear o seu texto com as referências centrais subjacentes à sua concepção nos permite afirmar, com pouca margem de dúvida, que as concessões que propõe às novas abordagens historiográficas são uma mera forma de chamar a atenção de inúmeros historiadores para os erros que estão sendo cometidos em nome da adesão irrestrita ao novo. Ou se- 
ja, Emília Viotti não propõe apenas uma síntese, pois, no final das contas, ela própria faz a sua opção pelo marxismo, porquanto seu olhar sobre as novas correntes não desprezou o contexto ("o mundo real”) do qual elas são originárias. Mas a historiadora não faz opção pelo marxismo economicista e determinista, mas pelo marxismo dialético, aquele que aprendeu a incorporar, a partir da capacidade de apreensão da realidade, o que de melhor a humanidade produziu no campo das idéias, promovendo sínteses fecundas entre as boas teorias, ao tempo em que descartava as meras ideologias.

\section{Paul Veyne e a História da ReVolução RUSSA DE TROTSKY: QUAL MARXISMO?}

Em meados dos anos 60, o historiador francês Paul Veyne, membro prestigioso da escola dos Annales, nos lançava uma questão intrigante. Ao discorrer sobre os significados (e significantes) da escrita da história, os componentes da "trama" e as noções de causalidade da historiografia em geral, e da historiografia marxista em particular, Veyne afirmou:

A distinção entre ocasiões e causas profundas se baseia na idéia de intervenção. Era assim que Trotsky raciocinava: com uma polícia decidida, nada de revolução de fevereiro de 1917; sem Lenine, nada de revolução de outubro; podiase contar com Stalin para aguardar, por muito tempo, a maturidade da história, e a Rússia seria hoje uma sociedade de tipo sul-americano. Entre 1905, em que ele não fez um só gesto, e 1917, Lenine passou da idéia causal de maturidade à idéia estratégica de 'ponto vulnerável da cadeia capitalista', e esse ponto vulnerável cedeu no país menos amadurecido, em relação à causalidade. Já que a história contém causas superficiais, isto é, eficazes, ela é estratégica, é uma sucessão de batalhas que compreendem um grande número de dispositivos diferentes e que são tantas as conjunturas especiais; é por isso que a Revolução Russa, de Trotsky, análise magistral de uma grande batalha histórica, não é um livro marxista, exceto por sua profissão de fé..$^{12}$

Está fora de questão discutir tanto as Teses de Abril de Lênin, momento em que ocorre sua mudança de compreensão estratégica quanto aos rumos da revolução na Rússia, quanto os postulados do historiador francês contidos na sua obra Como se escreve a história. O objetivo aqui é apenas atentar para o problema que nos apresenta Veyne e que nos interessa neste momento, qual 
seja, sobre o fato de a obra História da Revolução Russa, do líder revolucionário Leon Trotsky, não ser um "livro marxista, exceto por sua profissão de fé". Esta questão não é de menor importância nos marcos deste artigo sobre teoria e metodologia da história, visto que Marx, e os marxistas, se empenharam por longos anos em refletir acerca do "sentido" da história. Já que Paul Veyne não nos dá muitas pistas sobre o porquê de sua afirmação, nos caberá analisar brevemente a obra de Trotsky para tentar concluir "a qual marxismo" ele se referia.

Antes de prosseguir discutindo o historiador francês, lembremos, de passagem, que uma questão parecida nos foi apresentada por Norberto Bobbio, quando discutiu se Lênin era marxista ao analisar a sua defesa, e no final das contas implementação, de uma revolução socialista num país no qual as forças produtivas capitalistas ainda não se tinham desenvolvido completamente. ${ }^{13}$ Também o filósofo húngaro Georg Lukács enfrentou semelhante questão ao defender o "marxismo" de Rosa Luxemburgo quando esta travou polêmica contra os principais teóricos da social-democracia alemã no final da década de $1910 .{ }^{14}$ E mesmo o mais importante biógrafo de Trotsky, o polonês Isaac Deutscher, que escreveu a magistral trilogia O profeta armado, O profeta desarmado e $O$ profeta banido, não deixou de observar criticamente as posições de Trotsky quando este interpretou o papel de Lênin na história da Revolução Russa. ${ }^{15}$ Por fim, evocamos as passagens quase anedóticas das trajetórias de Marx e Trotsky, quando o primeiro afirmou não ser marxista e o segundo não ser trotskista, isso diante de discípulos que acreditavam muito seriamente nos ensinamentos dos seus mestres. Tivesse Lênin vivido o bastante e tivesse ele o humor de Marx e Trotsky, o seu legado, transformado em "marxismo-leninismo", provavelmente também lhe seria estranho, porquanto transfigurado numa vulgata economicista e inoperante. De fato, a questão, neste caso, também não é discutir sobre quem é ou não é marxista, mas chamar a atenção acerca do "marxismo" ao qual se referia Paul Veyne, na medida em que foi contra "aquele" marxismo que se levantou boa parte da historiografia nas últimas décadas, e com razão!

Voltemos então ao historiador francês. Este identificava os três tipos de fatores que estariam contidos na explicação histórica: o acaso, "causas superficiais, incidente, gênio ou oportunidade"; as causas materiais e objetivas e, por fim, a liberdade (causas finais). Veyne observa, e não sem razão, a opção preferencial do marxismo pelas causas materiais. ${ }^{16}$ Estas seriam, em última instância, os fatores determinantes da "consciência", ou, nas palavras do próprio Marx e de Engels: "Não é a consciência que determina a vida, mas sim a 
vida que determina a consciência". ${ }^{17}$ Portanto não se pode negar que o materialismo histórico fundou suas bases na premissa de que é do "ser social" que se ergue a "consciência" e não o contrário. Entretanto, se Marx e Engels enunciaram tal questão, em 1845, no bojo de um acirrado debate contra a filosofia idealista do seu tempo, questão que seria um dos fundamentos do materialismo histórico e da própria noção de dialética incorporada ao arcabouço do marxismo, não devemos desprezar que ambos os autores atentaram diversas vezes para as mediações que se estabelecem entre o mundo real e sua consciência possível, conforme apontamos anteriormente. Tanto que são notórias as assertivas contra o determinismo econômico aparecidas em diversos textos dos fundadores do materialismo histórico, especialmente naqueles destinados a analisar acontecimentos em curso. Nunca é demais lembrar a famosa passagem da abertura do 18 Brumário de Marx: "Os homens fazem sua própria história, mas não a fazem como querem; não a fazem sob circunstâncias de sua escolha e sim sob aquelas com que se defrontam diretamente, legadas e transmitidas pelo passado". ${ }^{18}$

Seria dispensável para os objetivos deste trabalho ficar discutindo se as “determinações" são "nessas" ou "naquelas" instâncias, e mesmo a discussão das causalidades históricas no pensamento de Marx e Engels não cabe neste texto, embora fosse muito apropriada para a compreensão do que seria uma historiografia marxista propriamente dita. De qualquer forma, muitos já fizeram essa discussão e a vasta bibliografia sobre o assunto está aí para quem quiser aprofundar-se. A citação dos textos marxianos serve apenas para lembrar que o próprio Marx, e também Engels, atentavam para as mediações possíveis na explicação histórica, especialmente o papel do homem como produtor de sua própria história.

Se o marxismo ao qual se referia Paul Veyne não observava tais mediações, isso não era, absolutamente, um problema dos fundadores do materialismo histórico. O próprio Trotsky chamou, categoricamente, a atenção para a questão no seu livro sobre a Revolução de 1905: "Aquele que for incapaz de admitir a iniciativa, o talento, a energia e o heroísmo no marco da necessidade histórica, não aprendeu o segredo filosófico do marxismo". ${ }^{19}$ Ora, o texto em questão foi escrito entre 1908 e 1909, portanto quase dez anos antes da Revolução Russa de 1917, e mais de vinte anos antes do seu livro História da Revolução Russa, citado por Veyne como "não marxista”. Como se vê, a compreensão de Trotsky quanto às mediações do "homem que faz a história", ou, dito de outra forma, quanto ao papel do indivíduo na história, acompanharam o marxista russo desde a sua juventude, e se houve alguma "profissão de 
fé”, elas não estavam relacionadas, como veremos, a uma heresia de Trotsky que assumiu, para além das causalidades últimas do movimento, inúmeras mediações possíveis. Isso porque, para o marxismo, as causalidades da história também estão relacionadas com as múltiplas temporalidades e ritmos do movimento histórico que, em circunstâncias extraordinárias, como numa revolução, por exemplo, obedecem mais substancialmente aos fatores "conscientes" do gênio humano. ${ }^{20}$ Trotsky havia percebido isso a partir da sua experiência prática e reflexão teórica em torno dos acontecimentos de 1905 na Rússia, tanto que foi capaz de formular a teoria da "revolução permanente" contra boa parte da liderança do POSDR, tanto a ala menchevique quanto a bolchevique, inclusive o próprio Lênin. Mas como não estamos discutindo a Revolução Russa, recorreremos apenas à sua análise do acontecimento e às noções de causalidade que enuncia:

Com efeito, uma sociedade não modifica as suas instituições na medida de suas necessidades, como um artífice renova seu instrumental. Ao contrário: a sociedade praticamente considera as instituições que a dominam como algo para sempre estabelecido ... São necessárias circunstâncias absolutamente excepcionais, independentes da vontade individual ou dos partidos, para libertar os descontentes dos estorvos do espírito conservador e levar as massas à insurreição. ${ }^{21}$

Portanto, em "condições normais", a sociedade tenderia sempre ao conservadorismo e somente em situações "absolutamente excepcionais", assim mesmo "independentes da vontade individual", é que se poderia levar a cabo a insurreição. Mas se o projeto de insurreição é "levado às massas", não o é simplesmente por obra e graça das "condições objetivas", porquanto se por um lado são os condicionantes exteriores que põem em marcha os "de baixo" contra os "de cima", é, sobretudo pelo ato de vontade (iniciativa, talento, energia, heroísmo), expresso pelo partido de vanguarda e seus dirigentes, que a insurreição logra êxito e consuma o projeto histórico das classes oprimidas.

Assim, devemos nos perguntar, mais uma vez, a qual "marxismo" Paul Veyne se refere. Se não era o marxismo de Trotsky e de tantos outros marxistas, talvez fosse o de Plekhanov, pioneiro do marxismo na Rússia que, no curso dos debates que empreendeu contra as correntes idealistas do início do século XX, terminou por subsumir o papel dos indivíduos e das subjetividades a causalidades gerais, o que teria propiciado uma certa interpretação esquemática da parte de muitos marxistas posteriores. ${ }^{22}$ É verdade que foi o marxismo de Plekhanov (também o de Bukharin e de Althusser), e não o de Trotsky, e, 
me arriscaria a dizer, o do próprio Marx, o difundido pelo mundo após a ascensão de Stalin e do seu "materialismo dialético" (diamat). Neste sentido, são passíveis de alguma consideração as críticas do historiador francês às "causalidades" últimas dos marxistas, visto ser a um certo marxismo que se referia.

Assim, afirma ainda Veyne: "A história não é uma construção disposta em andares em que uma base material e econômica sustentaria um andar térreo social no qual se sobreporiam superestruturas de destino cultural (ateliê de pintura, sala de jogos, gabinete do historiador); é um monólito em que a distinção de causas, de fins e de acasos é uma abstração" ${ }^{23}$ Como veremos em seguida, parte de sua assertiva poderia ser endossada por uma parcela dos marxistas, ao menos sob o aspecto de que nenhuma categoria dialeticamente apreendida pode ser estancada em compartimentos absolutamente distintos. Isto porque, entre a realidade e sua apreensão, nenhum conceito é imutável, de modo que entre o ser que existe e o que apreende há uma permanente articulação, negação e, finalmente, superação (aufhebung) através de uma transfiguração dialeticamente distinta da anterior.

\section{GRAMSCI: NECESSIDADE E IMPERATIVO DA VONTADE}

É verdade que Trotsky não pode ser chamado de "heterodoxo". ${ }^{24}$ Muito pelo contrário, o revolucionário russo pagou com a própria vida pelos princípios que defendeu de maneira intransigente. Depois de ser expatriado da União Soviética, em 1929, Trotsky percorreu boa parte da Europa em busca de um visto de permanência até terminar seus dias no México, onde foi assassinado por uma agente stalinista da GPU. Por isso, seria conveniente discutir um outro marxista, cuja obra monumental é, atualmente, bastante valorizada. ${ }^{25}$ Refiro-me ao italiano Antonio Gramsci, morto em 1937, poucos dias depois de ser libertado dos cárceres do fascismo. Italiano da região da Sardenha, Gramsci foi um dos maiores críticos do economicismo do "marxismo oficial". Na sua obra mais conhecida, os Cadernos do cárcere, o italiano empenhou-se em demolir boa parte das categorias marxistas vulgares produzidas em fins dos anos 20 e 30. São de sua lavra muitos dos conceitos largamente utilizados na historiografia e na sociologia contemporâneas, como as noções de "hegemonia", de "revolução passiva", de "classes subalternas" e de "intelectual orgânico", entre outras.

Gramsci dedicou sua vida à causa do socialismo. Quando foi preso, em 1927, tinha 36 anos, era Deputado do parlamento italiano e um dos princi- 
pais dirigentes do Partido Comunista, que ajudara a fundar em 1921. Na prisão fascista, Gramsci levou adiante seus estudos sobre a história da Itália de uma perspectiva marxista, muito embora sob profunda influência da filosofia idealista de Benedetto Croce, de onde extraiu elementos para a construção do seu conceito de hegemonia. ${ }^{26}$ Nesse ensejo, erigiu uma teoria profundamente antidogmática e antideterminista, em diálogo permanente com os clássicos do materialismo histórico, que Gramsci preferia chamar de "filosofia da práxis”. Na construção da sua concepção de história, o marxista italiano se deparou com a vulgata marxista então em franco processo de popularização, o que o obrigou a travar muitas batalhas no interior do marxismo. Um dos seus interlocutores preferenciais, a quem o italiano dirigiu as mais virulentas críticas, foi o dirigente soviético e principal artífice da política stalinista naqueles anos, Nikolai Bukharin e seu livro A teoria do materialismo histórico. Manual popular de sociologia marxista, referido por Gramsci sempre como Ensaio popular. ${ }^{27}$

Gramsci lia o marxismo da perspectiva da práxis política e filosófica, o que lhe permitia dialogar tanto com a herança marxista, a qual reivindicava, quanto com o legado do idealismo italiano, que tinha em Benedetto Croce seu principal representante. ${ }^{28}$ Em meados dos anos 30, muito em função do seu isolamento carcerário, mas também por suas posições "heterodoxas" ante o marxismo oficial da Internacional Comunista e do PCI, Gramsci sofreu certo ostracismo intelectual e político, sendo preterido da influência no partido e só alcançando a plena reabilitação depois de sua morte, em 1937. Alguns autores crêem mesmo que a subida do "porão ao sótão", reivindicada pela Nova História, teria sido antecipada pelo italiano cerca de quarenta anos antes do advento da terceira geração dos Annales. ${ }^{29}$ De qualquer forma, a obra de Gramsci não desprezava, em nenhum sentido, a anterioridade da matéria, do ser social ou da experiência, sobre a consciência, como os fundadores da "filosofia da práxis”. Porém, assim como Marx, Engels, e também Trotsky, Gramsci dedicava atenção especial para as mediações, o que tornava o seu marxismo um instrumento sempre vivo e dialético. Aliás, tinha predileção pela discussão das mediações políticas e culturais no movimento da história, tanto que uma das suas principais contribuições diz respeito à noção de intelectuais como mediadores culturais entre as classes sociais fundamentais e o mundo da cultura. ${ }^{30}$

Feitas as considerações iniciais, convém passar agora à parte da obra do marxista italiano que nos interessa nesta discussão. Apenas para não sairmos do campo das causalidades históricas, seria conveniente conhecermos a no- 
ção gramsciana de "necessidade". Esta resgata os princípios marxianos quanto a infra-estrutura e superestrutura, objetividade e subjetividade, estrutura e agência humana, de maneira que um aspecto não se subsume ao outro, mas, ao contrário, se intercalam e se articulam permanentemente, permitindo a transfiguração dialética dos fluxos históricos em contínua transformação.

Gramsci operava nesse campo de maneira extremamente cuidadosa, já que era justamente contra o marxismo determinista que esgrimia, e, muito em função dessa sua postura, corria o risco de ser tomado por idealista. De maneira que sua apreciação da história vem sempre acompanhada de uma profunda imersão na dialética do movimento, que reivindica tanto os elementos dos impulsos mais elementares da história, com suas forças objetivas operantes nos marcos da necessidade, quanto os elementos das forças subjetivas, submetidas fundamentalmente aos fatores da vontade humana. Sendo assim, Gramsci pretendia que a sua noção de "necessidade histórica" buscasse as "regularidades" das forças "relativamente permanentes", "não para descobrir uma lei metafísica de 'determinismo", nem nenhuma espécie de "lei geral de causalidade", mas para tomar a historicidade real de cada momento, para somente a partir daí formular as categorias mais adequadas ao contexto. Ou então, como dizia o próprio autor:

Existe necessidade quando existe uma premissa eficiente e ativa, cujo conhecimento nos homens se tenha tornado operante, ao colocar fins concretos à consciência coletiva e ao construir um complexo de convicções e de crenças que atua poderosamente como "as crenças populares". Na premissa devem estar contidas, já desenvolvidas, as condições materiais necessárias e suficientes para a realização do impulso da vontade coletiva; mas é evidente que desta premissa "material”, quantitativamente calculável, não pode ser destacado um certo nível de cultura, isto é, um conjunto de atos intelectuais, e destes (como seu produto e conseqüência), um certo complexo de paixões e de sentimentos imperiosos, isto é, que tenham a força de induzir a ação "a todo custo"."

Portanto, Gramsci entendia que sob cada circunstância de necessidade, seria absolutamente imprescindível uma "premissa eficiente", com condições suficientemente desenvolvidas para a realização do ato histórico. Esse ato não seria o resultado de uma objetivação qualquer do movimento histórico, e sim um ato "intelectual", de "cultura" e de "vontade". Sendo assim, teríamos, de um lado, as condições materiais da premissa, que deveriam ser "necessárias e suficientes", porquanto não se pode desconsiderar o impulso dos fluxos his- 
tóricos que independem da vontade humana; de outro lado, no que se refere às condições subjetivas, seria imperioso que houvesse um "complexo de paixões e sentimentos", sem os quais a "necessidade histórica" não se efetivaria, promovendo a superação dialética da realidade anterior. Ao que concluía Gramsci, "somente por este caminho é possível atingir uma concepção historicista (e não especulativo-abstrata) da 'racionalidade' na história (e, conseqüentemente, da 'irracionalidade')”. Ou seja, Gramsci reivindica o historicismo para se afastar do determinismo e do mecanicismo, ao mesmo tempo em que reivindica o marxismo para se manter longe dos idealistas.

Foi se insurgindo contra o materialismo mecanicista, e também contra a filosofia idealista, que o comunista sardo formulou seu postulado da "necessidade" que, articulado à "vontade", equilibra os elementos objetivos e subjetivos do fluxo histórico. Da mesma forma o italiano negava como "infantilismo primitivo" a idéia de que as flutuações na política e na ideologia eram expressões imediatas da infra-estrutura e, para reforçar seu argumento, recorria a Marx, que utilizava como critério fundamental para a suas formulações conceituais o seu olhar sobre a realidade e a historicidade de cada conjuntura. ${ }^{32}$ Refletindo dentro de uma lógica pouco explorada no interior do materialismo histórico, Gramsci foi um dos grandes marxistas do século XX, não obstante ser apreciado por pensadores liberais e adeptos de outras vertentes estranhas à sua própria corrente.

Lembremos que o postulado gramsciano da "vontade" em muito se assemelha às formulações de Trotsky que falava de "iniciativa", "talento" e "heroísmo". Em ambos os casos, tratava-se de dar combate às posições mecanicistas que reduziam todo o movimento a um emaranhado de determinações objetivas e causas necessárias e suficientes (observem que Gramsci fala de causas necessárias e suficientes, mas inclui o ato intelectual de cultura e vontade como elemento mediador definitivo à efetivação causal). Da mesma forma valorizava-se o papel do "homem" como agente da sua própria história, à maneira de Marx.

\section{SARTRE E O RESGATE DO HOMEM NO MARXISMO}

Não foi por acaso que Emília Viotti escolheu o filósofo francês Jean-Paul Sartre como seu contraponto argumentativo a algumas correntes da historio-

grafia contemporânea que trabalham com a análise do discurso e a teoria da linguagem. Esse filósofo de trajetória singular, que caminhou do existencia- 
lismo individualista ao marxismo humanista, representou tudo aquilo que as teorias pós-modernas, também chamadas de desconstrutivistas, pretendiam deixar para trás e enterrar junto com o século XIX. Foi a partir dos enfrentamentos com o estruturalismo, do qual a filosofia pós-moderna é uma das derivações, que a figura de Sartre se ergueu em nome do engajamento do intelectual e da centralidade do homem, sujeito de sua história. Foi também contra o descentramento da razão, que já se começava a promover naquela altura, e contra o marxismo estruturalista que Sartre bradou do alto de sua estatura de um dos maiores intelectuais do século XX.

De qualquer forma, como assegura François Dosse, para que o estruturalismo triunfasse, seria necessário que se "matasse" Sartre, figura tutelar da intelectualidade francesa do pós-guerra. ${ }^{33}$ De modo que o triunfo do estruturalismo na França, antecipando as modernas correntes pós-modernas, e tudo o que ele representava em termos de negação dos sujeitos, descentramento da razão e utilização em larga escala dos fatores inconscientes da história, entre outros fatores, a filosofia de Sartre foi sendo paulatinamente eclipsada, provocando incertezas e dúvidas, especialmente em relação ao existencialismo enquanto filosofia do sujeito: "O sujeito, a consciência, vão apagar-se em proveito da regra, do código, da estrutura”."

O homem sartriano sofrerá, assim, o primeiro grande revés com o advento do estruturalismo que ingressará nas ciências humanas através da antropologia de Claude Lévi-Strauss. Este introduzirá no conhecimento das coletividades humanas a noção de “inconsciente", em grande medida, uma importação da psicanálise. O segundo grande revés de Sartre será provocado por uma figura de proa da nova filosofia estruturalista, só que uma personalidade do interior do marxismo e de grande prestígio entre a intelectualidade francesa, especialmente aquela ligada ao PCF. Tratava-se do filósofo Louis Althusser e de suas leituras filosóficas de Marx, conduzido quase ao campo do pensamento puro, sem nenhuma influência da história real. Dessa forma, o pensamento de Sartre se prestará a dois combates simultâneos: de um lado, contra o estruturalismo em geral e, de outro, contra o estruturalismo marxista.

Contra o estruturalismo, portanto, Sartre formulou a sua "filosofia do engajamento", expressão maior de um pensador que reencontrava a realidade mediante o choque de um acontecimento de proporções universais: a Segunda Guerra Mundial. Com efeito, na sua principal obra "marxista", A crítica da razão dialética, e em seu capítulo introdutório, Questões de método, Sartre depõe sobre esse "encontro" inusitado entre um filosofo existencialista e a realidade da guerra, da Ocupação/Resistência e do movimento operário: 
Os acontecimentos políticos levaram-nos a utilizar como uma espécie de grade, mais cômoda do que verídica, o esquema de "luta de classes": mas foi necessária toda a história sangrenta desse meio século para levar-nos a apreender sua realidade e para situar-nos em uma sociedade dilacerada. Foi a guerra que fez explodir os enquadramentos envelhecidos de nosso pensamento. A guerra, a Ocupação, a Resistência, os anos seguintes. Desejávamos lutar ao lado da classe operária, compreendíamos, enfim, que o concreto é história e a ação é dialética. Tínhamos renegado o realismo pluralista por tê-lo reencontrado entre os fascistas e descobríamos o mundo. ${ }^{35}$

A partir desse seu "reencontro" com o mundo, Sartre passa a construir sua "filosofia do sujeito", centrando no homem, como agente de sua história, a razão de ser de toda a filosofia do presente e, conseqüentemente, do marxismo. Isto porque, para Sartre, "uma filosofia se constitui para dar expressão ao movimento geral da sociedade"; ela seria a forma pela qual "a classe 'ascendente’ toma consciência de si” e sua eficácia e permanência acompanhariam o momento histórico do qual ela seria a máxima expressão. ${ }^{36}$ Nesse sentido, para Sartre, a existência de uma determinada filosofia, e sua operacionalidade como modo de explicação do mundo, são determinadas pelas condições reais de existência em que ela se insere ou, como afirmou, "o concreto é história e a ação é dialética”. Portanto, qualquer outra tentativa de explicação teria muito mais um caráter de ideologia (falsa consciência), do que de uma filosofia propriamente dita. Essa "ideologia" permaneceria como tal, ou seja, como falsa consciência, enquanto existisse o mundo em que uma determinada filosofia seria apenas sua expressão. De outro modo, uma pretensa filosofia pode ou estar retornando a uma idéia pré-marxista, ou então ser uma expressão tautológica do próprio marxismo:

Com freqüência, tenho observado o seguinte: um argumento "antimarxista" não passa de um rejuvenescimento aparente de uma idéia pré-marxista. Uma pretensa "superação" do marxismo limitar-se-á, na pior das hipóteses, a um retorno ao pré-marxismo e, na melhor, à redescoberta de um pensamento já contido na filosofia que se acreditou superar. Quanto ao "revisionismo", trata-se de um truísmo ou de um absurdo: não há motivo para readaptar uma filosofia viva ao curso do mundo; por si mesma, ela opera tal adaptação através de mil iniciativas, mil pesquisas particulares, porque está intimamente ligada ao movimento da sociedade. ${ }^{37}$ 
Como vemos, Sartre vai ao limite da idéia de "necessidade", pois, ao incorporar o postulado marxiano segundo o qual a consciência é produto do ser social, admitia ser essa "filosofia" insuperável enquanto permanecessem as condições que a engendraram. Mas atente-se para a diferença em relação à vulgata, pois Sartre refere-se a produto, e não mero reflexo como pensavam os materialistas vulgares. ${ }^{38}$ Também expressa uma enorme profissão de fé na validade do marxismo, que terminava de abraçar. Nesse sentido, a filosofia marxista, segundo Sartre, porque cumpridora do papel assegurado pelas condições reais de existência, estava condenada a sobreviver, enquanto sobrevivessem as condições materiais que a engendraram. O marxismo seria a própria "filosofia tornada mundo". ${ }^{39}$

Mas, no final das contas, essa não é uma questão que está presente no argumento central deste texto e que tantas vezes já foi observado por inúmeros autores? Ou seja, não tem acontecido, com freqüência, que o marxismo tenha sido declarado morto e logo em seguida seja "ressuscitado" com o vigor improvável de um ente que torna sempre do além para assombrar o mundo dos vivos? Ou então, que muitas das críticas dirigidas ao marxismo, como a de Paul Veyne, por exemplo, não venham a encontrar a sua melhor expressão no interior da própria teoria que tentou superar? Voltaremos a essa questão ao longo deste texto.

Mas Sartre não se atém por muito tempo na própria trajetória e nem nas recentes descobertas que a guerra o ajudou a fazer. Passa imediatamente a discutir com desenvoltura a filosofia à qual aderira. Em Marx, Sartre encontra totalidades vivas, nunca entidades absolutas. Já no marxismo, entretanto, os fatos seriam tomados apenas como forma de "enriquecer o conhecimento" e "iluminar a ação". Para o filósofo francês, os conceitos, que seriam abertos em Marx, para o marxismo são fechados, deixando de ser esquemas interpretativos, para serem "saber totalizado". ${ }^{40}$ Contra a "esclerose da teoria" (de uma determinada teoria) marxista, limitada por um sem-número de noções apriorísticas, que, como já vimos, hegemonizou aquele campo teórico durante quase todo o século XX, Sartre propõe o reencontro com as mediações do "homem concreto" e dos "instrumentos ideológicos", com o "caráter do condicionamento de base que lhe criou". ${ }^{41}$ Nesse caminho, Sartre abre um flanco crítico também contra a teleologia e a explicação das coisas pela finalidade, típica do marxismo oficial, e propõe uma "hierarquia de mediações", que tenha no homem concreto e na singularidade de sua existência e das relações diversas que esse homem estabelece ao longo de sua vida, o ponto de partida. ${ }^{42}$

Como se vê, o marxismo de Sartre buscava reintroduzir o homem no in- 
terior da teoria do materialismo histórico. Não um homem abstrato e fetichizado, típico da filosofia idealista, mas o homem histórico, condicionado e condicionante da sua existência real. Já tínhamos visto como em circunstâncias diferentes, e também com inúmeras divergências que não pudemos abordar, as formulações filosóficas e metodológicas de Trotsky e de Gramsci tentaram algo parecido, nadando contra a corrente do marxismo do seu próprio tempo. Da mesma maneira que o pensamento dos seus "precursores", ao menos no caso específico do de Trotsky, a filosofia sartriana ainda aguarda o momento de sua redescoberta, para que se possa dotar o marxismo de um arsenal crítico, não apenas contra as teorias adversárias, mas também contra os reducionismos de algumas formas de "marxismos".

\section{THOMPSON E O PLANETÁRIO DE ERROS:}

O MATERIALISMO HISTÓRICO COMO EXPECTATIVA

Conforme observado por Emília Viotti, o legado de Sartre foi preterido em função de outras opções feitas pela historiografia contemporânea que preferiu retornar a Nietzsche, ou explorar a obra do sociólogo e teórico das relações internacionais Raymond Aron, como alternativa ao materialismo economicista do diamat. ${ }^{43}$ Além disso, o marxismo humanista de Sartre encontrou no anti-humanismo de Michel Foucault uma argumentação até certo ponto mais sofisticada do que a de muitos adversários marxistas e antimarxistas de sua época. Como se sabe, Foucault, que teria bastante influência nos anos 70 e 80 no mundo acadêmico francês, quando do lançamento da sua obra, foi saudado como revolucionário por ninguém menos do que Paul Veyne. ${ }^{44}$ Tratava-se de um filósofo que não apenas escrevia sobre a história, mas, também, escrevia obras históricas e que, além disso, tinha tido relações próximas com o marxismo e com o Partido Comunista Francês, as quais não foram adiante por conta de sua crítica visceral ao essencialismo do marxismo e seu primado da razão. ${ }^{45}$

Foi, entretanto, fora do continente que a mais importante historiografia marxista se desenvolveu, passando ao largo da vulgata do stalinismo e do estruturalismo. Com efeito, a corrente de historiadores ingleses ligados à New Left Review não apenas não tinha vinculação com o marxismo mecanicista do diamat, como surgiu criticando o escolasticismo e a esterilidade do materialismo histórico do pós-guerra. Apesar disso, a primeira escola de boa parte desses historiadores foi justamente o Partido Comunista da Grã-Bretanha, orga- 
nização onde exerceram a militância e praticaram a historiografia, até pelo menos 1956, quando alguns deles saíram do PC e seguiram por outros caminhos para fundar a Nova Esquerda, não obstante ainda no interior da esquerda e dentro do campo do marxismo. ${ }^{46}$ Entre os historiadores britânicos dessa corrente, também chamada de história social inglesa, destacam-se Maurice Dobb, Christopher Hill, Rodney Hilton, Eric Hobsbawm e Edward Thompson. ${ }^{47}$ Este último, cuja obra monumental foi quase toda ela dirigida ao estudo da classe operária e das culturas subalternas, dedicou-se, em alguns momentos, a travar um acirrado debate contra o estruturalismo marxista. Esse foi o objetivo do seu texto polêmico mais famoso, de 1978, A miséria da teoria. ${ }^{48}$

No livro, dedicado a polemizar de maneira virulenta com o pensamento do filósofo Althusser, aparecerão elementos das críticas de Trotsky, Gramsci e Sartre aos marxismos do seu próprio tempo. Apesar disso, Thompson não reivindica nenhuma dessas tradições ao descerrar seus argumentos contra o planetário de erros. ${ }^{49}$ Os ataques de Thompson ao estruturalismo de Althusser, em certa medida também valiam para boa parte do estruturalismo em geral. Porque feitos por um historiador nosso contemporâneo e de grande reputação no meio acadêmico, tiveram, também, muito mais ressonância nos meios intelectuais e universitários do que as críticas dos demais marxistas que abordamos neste artigo..$^{50}$ Assim, considero desnecessário enumerar todos os postulados dos seus argumentos, visto já serem por demais conhecidos entre nós, historiadores de profissão. De qualquer forma, para o leitor um pouco menos familiarizado com os textos thompsonianos, e para a nossa própria discussão, será imprescindível uma pequena digressão a guisa de introdução ao rico pensamento de Edward Palmer Thompson.

Para Thompson, o marxismo de Althusser, apresentado nos seus dois textos mais importantes, A favor de Marx e Ler o Capital, nada mais era do que uma forma de idealismo "com atributos de uma teologia". ${ }^{51} \mathrm{O}$ abandono, pelo marxismo estruturalista, da noção de "experiência", que era matéria-prima da demonstração de discursos históricos, implicaria inúmeros problemas de ordem teórica e prática, pois, ao prescindir do diálogo necessário entre "ser social" e "consciência social", o materialismo histórico perderia suas referências principais.

Contudo, apesar de reivindicar o lugar da experiência na história e, portanto, no materialismo histórico, Thompson não está invalidando o papel da teoria ou mesmo proclamando o "empiricismo" como a forma mais correta de se lidar com a história. Pelo contrário, o procedimento adequado para o trabalho com materiais históricos, dizia Thompson, pressuporia um método 
que articulasse o diálogo permanente entre teoria e prática, entre hipóteses e evidências. A experiência surgiria, assim, desse diálogo necessário entre "ser social" e "consciência social", compondo uma espécie de "dialética do conhecimento histórico". O resultado desse conhecimento seria submetido ao julgamento do "tribunal dos recursos", cujo parecer exarado, sempre a posteriori, validaria ou refutaria o conhecimento produzido, conformando uma "dialética do conhecimento histórico".52

Nesse sentido, o materialismo histórico, como todo o conhecimento histórico, disporia seus materiais e recursos para serem julgados pelo "tribunal", e não obteria nenhum tipo de validação apriorística, por serem a teoria da classe trabalhadora, ou expressão de uma dada "consciência" contra uma "falsa consciência”. O próprio materialismo histórico também estaria sendo submetido ao julgamento implacável dos “juízes" do "tribunal”. As categorias empregadas pelo materialismo histórico serviriam, então, mais como expectativas do que como regras, na medida em que os "conceitos" e as "regras" históricas exibiriam toda uma elasticidade própria, além de irregularidades diversas. Mas não seria esse o "nó górdio" daqueles que acreditam ser a história uma "ciência" experimental? Ou então, a história não tem provocado desconfianças epistemológicas variadas da parte de outras disciplinas e dentro do próprio métier dos historiadores? ${ }^{53}$

Portanto, numa disciplina com tamanha irregularidade e elasticidade, as noções de causalidade e sentido ficariam submetidas sempre à investigação empírica, que poderia encontrar tendências e, somente assim, promover algumas generalizações. Isto porque, para Thompson, a história conheceria causas necessárias, mas nunca suficientes, "pois as 'leis' (ou, como prefiro, a lógica ou as pressões) do processo social e econômico estão sendo continuamente infringidas pelas contingências, de modos que invalidariam qualquer regra nas ciências experimentais, e assim por diante". Dito de outra forma, "A história não conhece verbos regulares". ${ }^{54}$

A peculiaridade de Thompson e dos marxistas ingleses estaria, portanto, na valorização da cultura e da experiência como elementos centrais na análise da história. Concomitantemente, a recusa veemente de apriorismos de qualquer espécie. Não por acaso, alguns autores ao detectarem certa "heterodoxia", caracterizaram como "culturalista" o marxismo daquela corrente de historiadores, à qual poderia ser acrescentada a personalidade do crítico literário Raymond Williams. ${ }^{55}$ De uma forma ou de outra, os marxistas ingleses criticaram como ninguém a redução economicista promovida por um certo tipo de marxismo. Em alguma medida, não pouparam nem mesmo os fun- 
dadores do materialismo histórico, em especial o Marx maduro, aquele que se dedicou por décadas a estudar $O$ capital, e negaram veementemente a utilização da metáfora "base e superestrutura".

Nesse ponto, foi ainda Thompson quem erigiu uma substancial revisão de alguns postulados essencialistas do materialismo histórico, por considerálos inadequados. Neste sentido, buscou ressignificar a categoria de "classe", retirando-a do campo "essencialista" da estrutura e inserindo-a no campo das identidades e relações constituídas historicamente. Ou, nas palavras do próprio autor: "Nenhuma categoria histórica foi mais incompreendida, atormentada, transfixada e des-historicizada do que a categoria de classe social; uma formação histórica autodefinidora, que homens e mulheres elaboram a partir de sua própria experiência de luta, foi reduzida a uma categoria estática, ou a um efeito de uma estrutura ulterior, das quais os homens não são os autores, mas os vetores". ${ }^{57}$ Entre as categorias de Thompson, essa foi a mais utilizada pelos estudos que buscaram superar os limites teórico-metodológicos do marxismo então praticado.

No percurso de consecução dos seus trabalhos, Thompson e os demais marxistas ingleses legaram para a historiografia uma metodologia bastante apreciada pelos que trabalham com materiais históricos, em que se recortavam, no fundamental, as classes sociais em um permanente processo de "fazer-se". Daí se abstrairiam a experiência, a cultura, a política e tudo aquilo que no marxismo dogmático, determinista, mecanicista ou estruturalista — tenha ele o adjetivo que tiver - foi deixado de lado em nome de um método que, conforme discutimos, não remonta necessariamente a Marx e Engels, nem foi unanimidade entre os marxistas no seu conjunto.

A proposição inicial da qual partimos foi a da "inversão da dialética" da parte de alguns textos da recente historiografia, sugerida pela historiadora Emília Viotti da Costa. Conforme a nossa interpretação, não se tratava apenas de uma "inversão da dialética", e sim de sua transfiguração e abandono, ao menos para um segmento da historiografia identificada com o chamado pós-modernismo. Isso teria ocorrido porque, entre outros motivos, a "dialética" era procurada nos textos de um determinado marxismo até certo ponto antidialético. Por isso achamos necessário identificar algumas sínteses que já vinham sendo praticadas por várias gerações de marxistas e, como vimos, em alguns casos, provocaram o estranhamento de um historiador como Paul Veyne. Mas se um segmento da historiografia optou por desprezar a dialética, não pensamos que esta seja uma posição unânime. Alguns trabalhos, conceitos e categorias, utilizados atualmente em diversos trabalhos, também expres- 
sam a presença de sínteses ricas, quando não, a impressão de que a dialética de fato nunca deixou de freqüentar os salões de gala de determinados historiadores. Se não, como poderíamos prescindir das categorias fundamentais ensejadas por Trotsky e Gramsci quanto ao papel dos indivíduos (classes e partidos) no interior da necessidade histórica? Ou então, como ignorar a reivindicação da centralidade do homem na história de Sartre? Por fim, como desprezar a idéia de que as categorias do materialismo histórico servem muito mais como expectativa do que como certezas aprioristicamente aplicáveis a todas as circunstâncias? É verdade que a historiografia não resolveu todos esses problemas de maneira satisfatória, mas a dialética continua sendo tanto um método epistemológico, um princípio ontológico e um movimento real da história, conforme a pressupunha Marx em seus textos mais importantes. ${ }^{58}$

\section{ANÁliSE DO DISCURSO, TEORIA LITERÁRIA E LINGÜÍSTICA: CLIO REVISITADA}

Quando um historiador da estatura de Carlo Ginzburg se dedicou a discutir questões metodológicas da história, era um sinal de que Clio precisava de auxílio. Isto porque, conforme uma advertência sua, publicada num dos seus últimos livros, não era muito comum que os teóricos da historiografia se dedicassem a trabalhos concretos e, inversamente, que historiadores dedicados a estudos específicos fossem ardorosos amantes da discussão teórica: "Raramente a distância entre reflexão metodológica e prática historiográfica efetiva foi tão grande quanto nos últimos decênios". ${ }^{99}$

Sobre o assunto, o próprio Thompson já se havia referido, quando chamava a atenção, na abertura d'A miséria da teoria, para "uma certa letargia conceitual" e negligência nas "linhas de abastecimento teórico", ao menos da historiografia marxista que compartilhava. ${ }^{60}$ Não era de surpreender, portanto, que num capítulo específico do livro dedicado a apontar o planetário de erros de Althusser, Thompson abrisse um "intervalo" para discutir o que chamou - no nosso entendimento, muito apropriadamente — de "lógica histórica”. No capítulo, o historiador inglês relata, de maneira quase anedótica, o "estranhamento" dos antropólogos que, num determinado seminário, não conseguiram disfarçar a hilaridade quando Thompson remeteu a validação de um determinado discurso histórico à questão da "lógica histórica". ${ }^{61}$

De fato, como sugere Ginzburg, foram poucos os historiadores que se dedicaram a discutir as operações fundamentais das suas próprias práticas. E lembremos que os exemplos que buscamos, com exceção do de Thompson, 
foram tomados de dois revolucionários e militantes de partidos comunistas, Trotsky e Gramsci, e de um filósofo engajado, Sartre. Talvez a exceção mais óbvia a essa tal "letargia conceitual" possa ser exemplificada pela historiografia produzida pelos Annales. Entretanto, afora em trabalhos isolados de Marc Bloch, Lucien Febvre ou Fernand Braudel, seria somente a partir da chamada Terceira Geração que os historiadores se empenhariam de fato em erigir um paradigma ou pensar mais teoricamente sobre sua própria disciplina. No entanto, àquela altura, o que terminaram conseguindo realizar foi apenas um inventário das diferenças e das idiossincrasias que os separavam.

Foi, portanto, a partir da importação de modelos teóricos e metodológicos das outras disciplinas das ciências humanas que a história se desenvolveu conceitualmente. Houve o tempo da sociologia, da psicologia e, principalmente, da antropologia, que durante longos anos nutriu a história de conceitos-chave, como o de cultura, por exemplo (cultura material, cultura simbólica, cultura popular e cultura de elite, entre outras), que foi incorporado ao arsenal do historiador com muita propriedade e força, informando boa parte dos trabalhos produzidos por várias décadas. ${ }^{62}$

Ultimamente, as disciplinas "da vez" são a lingüística e a teoria literária. Com efeito, muito em função da influência da obra de Michel Foucault, um determinado nicho de historiadores passou a refletir sobre o próprio ofício a partir da "análise dos discursos". ${ }^{3}$ Por conseguinte, foram introduzidos no "discurso histórico" conceitos como representação, apropriação, inconsciente (este, relacionado também à psicanálise e ao uso da antropologia, conforme já nos referimos), entre outros vinculados não apenas à lingüística e à teoria literária, mas também à semiótica e à filologia. Nesse caminho, alguns historiadores passaram a chamar a atenção para um elemento de todo desprezado pela historiografia dita tradicional: a questão da narrativa. Esta apareceria como uma das formas mais apropriadas de enunciação do discurso histórico, e aqui não pretendo entrar no debate sobre o problema de se considerar todo e qualquer texto histórico uma narrativa. $\mathrm{O}$ fato era que a narrativa (res)surgia com o vigor de um discurso que não apenas pretendia aprimorar a forma, mas também adequar o conteúdo, antes preocupados com os "grandes porquês" da história. Clio passava a ser vista por alguns, acima de tudo, como uma narrativa. Esta seria de tal forma, em si mesma, referente, que as diferenças em relação à literatura ficcional quase desapareciam. Questionavam-se as noções de realidade e de verdade histórica, e tomava-se a retórica como substância inerente do discurso, recusando-se os referentes extratextuais e as categorias explicativas diversas. ${ }^{64}$

Decerto que as importantes contribuições à história, da parte da teoria li- 
terária e da lingüística, não podem ser desprezadas, e está fora de questão refutá-las em bloco. Também não é nosso propósito discutir como os historiadores que aderiram a essas correntes, muito comumente chamadas de pós-modernas, utilizaram ou abandonaram a dialética nos seus trabalhos, de forma que o movimento da história, ou as relações de sentido que projetam o futuro como superação do passado, desapareceram completamente de boa parte dos trabalhos históricos recentes. Pretendo, pelo contrário, apontar algumas das possibilidades existentes atualmente em uma parcela da historiografia, em especial da historiografia brasileira, que não abandonou a noção de "realidade" extratextual e referente. Assim, optei por apontar, ainda que sumariamente, muitas narrativas que continuam a utilizar a dialética e suas categorias fundamentais de contradição, movimento e totalidade, sem, entretanto, desprezar os papéis das subjetividades e do particular na realização das sínteses necessárias. De modo que as contribuições imprescindíveis de autores como Trotsky, Gramsci, Sartre e Thompson, além de Marx e Engels, naturalmente, embora de maneira desigual, convivem perfeitamente com inúmeros trabalhos que incorporaram muitas das contribuições de outras disciplinas, sem desprezar a idéia de que, para além do mundo aparente, há um mundo que necessita de um método para ser descortinado. Este método pode ser chamado de dialética.

\section{A DIALÉTICA PRESENTE}

Como já foi dito, a historiografia contemporânea produziu significativas sínteses que combinam o método dialético, presente nos autores discutidos, com as recentes preocupações dos historiadores quanto aos temas ligados à autonomia relativa de que os seres humanos dispõem em algumas circunstâncias, especialmente nos espaços da ação política, em momentos decisivos, e da cultura em geral. A partir dos trabalhos empíricos dos historiadores marxistas britânicos, especialmente Christopher Hill, Edward Thompson e Eric Hobsbawm, podemos perceber como tais autores puderam tratar de temas anteriormente entendidos por um certo marxismo como meros reflexos de uma base (infra-estrutura) econômica. Seria desnecessário enumerá-los e qualquer um que queira pode achar boa parte dos seus textos traduzidos para o português.

Além da historiografia inglesa, outra importante escola que promoveu sínteses substancialmente importantes poderá ser encontrada nos trabalhos da micro-história italiana, principalmente as obras de Carlo Ginzburg e Giovanni 
Levi, também traduzidas para o português. Em que pese o fato de que tais historiadores não se situam necessariamente no campo do marxismo, o que se percebe é que as categorias dialéticas (especialmente movimento, contradição e totalidade) permeiam toda a narrativa imbricada de margens de autonomia da ação humana, por vezes estreitas, por vezes mais largas. Também os historiadores da micro-história italiana, muito embora incorporando mais decididamente do que os seus colegas britânicos muitas das conceituações formuladas por outras disciplinas das Ciências Humanas e Sociais, não prescindem, em nenhum momento, das noções centrais de realidade e verdade, entendidas como entidades concretas extratextuais. Como assinalou Hobsbawm, o que poderia ser reforçado por qualquer micro-historiador da escola de Ginzburg e Levi,

defendo vigorosamente que aquilo que os historiadores investigam é real. O ponto do qual os historiadores devem partir, por mais longe que possam chegar, é a distinção fundamental e, para eles, absolutamente central, entre fato comprovável e ficção, entre declarações históricas baseadas em evidências e sujeitas a evidenciação e aquelas que não o são. ${ }^{65}$

Há que se assinalar que a dialética não opera conceitualmente a partir da própria idéia, conformando "tipos ideais", à maneira de Weber. Ao contrário, ela pressupõe a existência de um mundo real, dotado de significados e tendências gerais de movimento e sentido. Esse mundo não pode ser tomado apenas em sua aparência, pois só pode ser verdadeiramente apreendido na sua essência, a partir da aplicação do método dialético, que implica a aceitação de determinados princípios quanto ao movimento (transformação da quantidade em qualidade, interpenetração dos contrários e negação da negação). E um historiador como Hobsbawm pretende nos alertar para que a "história está empenhada em um projeto intelectual coerente, e faz progressos no entendimento de como o mundo passou a ser como é hoje”. ${ }^{66}$ Portanto o historiador deve buscar as regularidades da história, para a recuperação dos sentidos profundos do movimento, já que este não é de todo incoerente.

De um ponto de vista semelhante, Carlo Ginzburg também procurou refutar o uso da retórica feito por alguns historiadores pós-modernos (ou relativistas céticos, como prefere o italiano), descolado das noções de prova referenciadas em realidades históricas extradiscursivas. Afirmando compartilhar com um outro historiador italiano, Arnaldo Momigliano, a noção de que encontrar a verdade é o objetivo fundamental de todo pesquisador, "inclusive os historiadores", Ginzburg defende a impossibilidade de redução da história 
à retórica, porquanto as suas provas seriam, dentro da tradição aristotélica, o "núcleo fundamental" da própria retórica. ${ }^{67}$

As premissas de uma história dialética também podem ser vistas a partir das categorias trabalhadas por esses historiadores, que não abandonaram as noções de contradição, a partir do recorte de classe (ou correlatos), de movimento, relacionada à combinação de condicionantes e causalidades múltiplas, e de totalidade, já que os homens como sujeitos históricos aparecem não como "fragmentos" de identidades diversas, mas articulados ao conjunto das estruturas e conjunturas em que estavam inseridos. Desse conjunto de pesquisas, surgiram categorias novas, plenamente historicizadas e incorporadas ao jargão historiográfico e dialético, como "identidade", "circularidade cultural" e "incorporação seletiva", entre outras.

Mas não são apenas os trabalhos de historiadores estrangeiros que devem ser citados como exemplos das sínteses que incorporaram as novas metodologias ao "velho" método dialético. Muitos autores da historiografia nacional já compreenderam a necessidade de se buscar, nas novas categorias da historiografia contemporânea, referências adequadas na combinação dos componentes da agência humana e das objetivações estruturais. Neste sentido, convém citar os conhecidos trabalhos de João José Reis, Silvia Hunold Lara e Sidney Chalhoub, apenas para nos referirmos a uns poucos exemplos, que estiveram inseridos no boom da historiografia da escravidão em finais dos anos $80 .{ }^{68}$ Mais recentemente a própria Emília Viotti da Costa produziu uma magnífica narrativa sobre a revolta dos escravos de Demerara.$^{69}$ Para tais autores, com variações de abordagem de caso a caso, o fundamental é entender como se deu a resistência de homens e mulheres comuns à escravidão, nos marcos de um sistema profundamente violento que deixava poucas margens de autonomia aos seres humanos. Nas suas abordagens, os historiadores da escravidão demonstraram que não se podem desprezar os componentes subjetivos na construção e efetivação da resistência.

Também a história social do trabalho no século XX tem ressignificado muitas das suas noções no processo de composição das necessárias sínteses contemporâneas. ${ }^{70}$ Nestas áreas, as influências da história social inglesa são as mais evidenciadas, especialmente quanto às noções de "classe", "cultura" e "identidade" (também presentes entre os historiadores da escravidão), tomadas dos trabalhos de Thompson. Outras categorias também aparecem de maneira recorrente, como "multidão" e "economia moral", como importantes instrumentos de análise das situações concretas. Também será nessa área que o conceito grams- 
ciano de "hegemonia" aparecerá aplicado e reinterpretado, de acordo com as inúmeras contribuições de historiadores contemporâneos, conforme o caso.

Por fim, gostaria de mencionar alguns dos novos trabalhos da historiografia política e social da segunda metade do século XX que combinam as margens estreitas em que a necessidade e a liberdade se conjugam, se negam e se determinam recíproca e dialeticamente. Neste ramo, os trabalhos dos sociólogos e politicólogos imperavam absolutos. Entretanto, na última década, uma quantidade imensa de bons textos têm procurado refazer os caminhos dos atores do passado, a partir dos referenciais de uma historiografia do presente. ${ }^{71}$ Bastante informada pelos autores citados, especialmente pelos marxistas ingleses, entretanto sem abandonar outros autores do materialismo histórico, tal historiografia tem se inspirado sobremaneira numa ampliada noção do "político", conforme nos propôs o historiador francês René Rémond há pouco mais de uma década. ${ }^{72}$

É dessa nova lavra da história política e social brasileira um texto recente que, apenas a título de exemplo, tomarei neste artigo. $\mathrm{O}$ trabalho coletivo revisita uma das categorias mais importantes da história política nacional e latino-americana: o conceito de "populismo". Por conseguinte, conforme nos sugere o historiador Jorge Ferreira, da Universidade Federal Fluminense, organizador da coletânea, a noção de populismo, como elaboração de um determinado discurso dos agentes do passado, e como formulação teórica do meio acadêmico universitário, cristalizou-se como um senso comum na cultura política brasileira e somente agora passa a ser revisitada e reinterpretada. Isso estaria acontecendo muito em função da entrada dos historiadores no cenário dos intérpretes do nosso passado recente, área, como disse, ocupada quase exclusivamente por sociólogos e cientistas políticos. A noção de "populismo", e sua devida contestação ou legitimação, ganharia, assim, seu lugar na história com um conjunto de trabalhos de historiadores dedicados a estudar as implicações de um tal uso na historiografia. Dessa maneira, seria a partir da releitura do contexto em que o termo teria surgido, e também dos significados e implicações que o seu uso embutia, que tais historiadores resolveram reavaliar a adequação no uso de uma expressão e de um conceito tão difundidos. A conclusão dos autores foi pela relativização do conceito, aplicado, no mais das vezes, de modo genérico e sem a contextualização adequada. Portanto, ao se buscarem as origens do termo e da formulação do conceito, tais historiadores procuraram apreender em que medida uma "expressão", demasiado genérica, poderia corresponder a uma prática política particular de um país, ou um conjunto de países, de um continente; ou, dito de outra forma, o 
que se pretendia era procurar entender sob quais aspectos um tal "nome" (populismo) corresponderia a uma tal "coisa” (prática política específica de alguns países latino-americanos num determinado período).$^{73}$

Por fim, já era chegado o momento de se cobrar a parcela dos historiadores na construção do conhecimento humano como um todo e de se verificar que tipo de retribuição esse ramo do conhecimento poderia proporcionar às outras áreas que sempre doaram conceitos, categorias, teorias e metodologias variadas, mas pouco receberam em troca. Como estudioso do passado, vislumbro que talvez o maior auxílio que poderá dar um historiador ao estudo da história recente, por mais tautológica e redundante que possa parecer a assertiva, é justamente a indicação da necessidade de historicização de todos os processos e categorias da história e das ciências humanas. Nesta medida, a dialética como método, ontologia e movimento, deverá se fazer presente, operando as sínteses necessárias e articulando as totalidades do concreto no curso do processo histórico, dando também a sua contribuição ao novo conhecimento.

Assim, não correremos o risco de fragmentar, nem desistoricizar o nosso passado, a ponto de suprimirmos os seus sentidos profundos. Refiro-me a "sentidos", sem pressupor causalidades e necessidades absolutamente imanentes, senão em tendências cujas condições necessárias estejam dadas, mas que sem o impulso da vontade, não se efetivam. Penso essencialmente nos sentidos que todo historiador deverá buscar no passado para dotar as suas explicações da inteligibilidade necessária aos textos históricos. De outra forma, seríamos levados ao mais absoluto ceticismo, frente às agruras de um real que nos aparece ininteligível e que não conseguimos explicar sem os instrumentos da teoria. Ou, para ficar nas palavras de Antonio Gramsci:

Todos os mais ridículos fantasistas, que em seus esconderijos de gênios incompreendidos fazem descobertas espantosas e definitivas, precipitam-se sobre todo o movimento novo, convencidos de poder vender suas tolices. De resto, todo o colapso traz consigo desordem intelectual e moral. É necessário criar homens sóbrios, pacientes, que não se desesperem diante dos piores horrores e não se exaltem em face de qualquer tolice. Pessimismo da inteligência, otimismo da vontade. ${ }^{74}$

\section{NOTAS}

${ }^{1}$ Agradeço a leitura e os comentários dos professores Aldrin Castellucci, Muniz Ferreira e Socorro Ferraz. Sou grato também a Patrícia Novais e Hilda Eloysa, pelo estímulo e incen- 
tivo. Nunca é demais advertir que os eventuais erros e omissões deste texto são de minha exclusiva responsabilidade.

${ }^{2}$ Professor Assistente da Universidade do Estado da Bahia — UNEB, Campus II, Alagoinhas. Doutorando em História na Universidade Federal de Pernambuco - UFPE. zacasenajr@uol.com.br.

${ }^{3}$ A referência completa dos dois artigos é: COSTA, E. V. da. Estrutura versus experiência. Novas tendências da historiografia do movimento operário e das classes trabalhadoras na América Latina: o que se perde e o que se ganha. Boletim Informativo e Bibliográfico de Ciências Sociais (BIB). Rio de Janeiro, n.29, p.3-16, 1ํsem. 1990; A dialética invertida: 1960-1990. Revista Brasileira de História. Brasil: 1954-1964. São Paulo: ANPUH/Marco Zero, v.14, n.27, p.9-26, 1994.

${ }^{4}$ COSTA, E. V. da. Estrutura versus experiência, cit., p.10.

5 "Maio de 68, refez-se o mundo. Maio de 86, reforma-se a cozinha".

${ }^{6}$ COSTA, E. V. da, op. cit., p.9-10 (todas as citações encontram-se nessas páginas).

${ }^{7}$ Ibidem, p. 12.

${ }^{8}$ Ibidem, p.15-7.

${ }^{9}$ Ibidem, p.19-20.

${ }^{10}$ Refiro-me a transformações "reais ou imaginárias" acompanhando o raciocínio de Emília Viotti que observou o impressionismo da historiadora Michelle Perrot em relação às questões que afligem o mundo contemporâneo: "Quando eu ouço Michelle Perrot, uma das historiadoras de vanguarda na França, dizer numa entrevista que a sociedade pós-moderna é uma sociedade em que as possibilidades de expressividade individual se multiplicaram, que o impacto dos sistemas políticos e dos modelos culturais têm sido exagerados e que afinal de contas as pessoas ainda têm sua vida privada, que suas faculdades críticas são cada vez mais desenvolvidas porque um maior número de pessoas são educadas, eu me pergunto se de fato essa observação se aplica às camadas populares tanto nos países periféricos quanto no centro. Mas quando Perrot afirma que a sociedade pós-moderna é uma sociedade em que as pessoas têm um respeito muito maior umas pelas outras, eu me pergunto em que mundo ela tem vivido". Ibidem, p.23-4.

${ }^{11}$ Ibidem, p.24-6.

${ }^{12}$ VEYNE, P. Como se escreve a história e Foucault revoluciona a história. Brasília: Ed. UnB, 1995, p.59. Grifos meus.

${ }^{13}$ Trata-se do capítulo intitulado "Lênin era marxista?”. In: BOBBIO, N. As ideologias e o poder em crise. Trad. João Ferreira. Brasília: Ed. UnB, São Paulo: Polis, 1988, p.62-6.

${ }^{14}$ LUKÁCS, G. História e consciência de classe. Estudos de dialética marxista. Trad. Telma Costa. 2.ed. Rio de Janeiro: Elfos, Porto: Publicações Escorpião, 1989, p.41-58.

${ }^{15}$ Para Isaac Deutscher, Trotsky tinha tido uma "ilusão de ótica" quanto ao papel de Lênin. 
Segundo esse autor, tal ilusão estava relacionada com o estado de espírito do revolucionário russo que escrevia seu texto no auge da "orgia" do culto da personalidade stalinista, portanto contra o Stalin “insubstituível”, um Lênin também “insubstituível”. DEUTSCHER, I. Trotski: o profeta banido. 1929-1940. Trad. Waltensir Dutra. 2.ed. Rio de Janeiro: Civilização Brasileira, 1984, p.250-6. Como veremos, diferentemente do que afirma o biógrafo polonês, as leituras do Trotsky da História da Revolução Russa, escrito nos anos 30, não serão muito diferentes das do Trotsky da Revolução de 1905, escrito entre 1906 e 1908.

${ }^{16}$ VEYNE, P., op. cit., p.56.

${ }^{17}$ MARX, K., ENGELS, F. A ideologia alemã. Trad. Luís Cláudio de Castro e Costa. São Paulo: Martins Fontes, 1989, p.21.

${ }^{18}$ MARX, K. O 18 Brumário e Cartas a Kugelman. Trad. Leandro Konder. 6.ed. Rio de Janeiro: Paz e Terra, 1997, p.21.

${ }^{19}$ TROTSKY, L. A Revolução de 1905. Trad. Salvador de Freitas. São Paulo: Global, s.d., p.55.

${ }^{20}$ Sobre o assunto, ver o texto esclarecedor de ARCARY, V. Controvérsias marxistas sobre o papel do indivíduo na História. Crítica Marxista. São Paulo: Boitempo, n.15, p.35-56, out. 2002.

${ }^{21}$ TROTSKY, L. História da Revolução Russa. Trad. E. Huggins. 2.ed. Rio de Janeiro: Paz e Terra, 1977, v.1, p.16.

${ }^{22}$ PLEKHANOV, G. O papel do individuo na história. In: Concepção materialista da história. 7.ed. Rio de Janeiro: Paz e Terra, 1987, p.72-112. Apesar de não ter a estatura intelectual e dirigente de Lênin ou Trotsky, Plekhanov, o "pai do marxismo russo", foi um dos mais influentes marxistas do seu tempo e seu legado perdurou por muitos anos, tanto em território soviético quanto no âmbito da Internacional Comunista. Cf. BOTTOMORE, T. Dicionário do pensamento marxista. Trad. Waltensir Dutra. 2.ed. Rio de Janeiro: Zahar, 1988, p.286-7.

${ }^{23}$ VEYNE, P., op. cit., p.55.

${ }^{24}$ Apesar de espinhosa, uso a noção de "ortodoxia" e "heterodoxia" livremente, sem adentrar as querelas que envolveram diversos partidários do marxismo ao longo dos anos.

${ }^{25}$ Recentemente um projeto editorial da Civilização Brasileira concluiu a publicação dos seis volumes dos Cadernos do cárcere, de Antonio Gramsci, e dos dois volumes dos seus textos pré-carcerários escritos entre 1910 a 1916. Além disso, há a previsão de lançamento das Cartas do cárcere. O projeto está sob a coordenação do professor Carlos Nélson Coutinho, da UFRJ.

${ }^{26}$ Sobre a influência do pensamento de Croce na obra de Gramsci, veja-se o trabalho de DIAS, E. F. Gramsci em Turim: a construção do conceito de hegemonia. São Paulo: Xamã, 2000, p.23-50.

${ }^{27}$ Teórico de muitos recursos, Bukharin foi um dos principais quadros do regime stalinis- 
ta. No curso dos debates sobre a NEP, perfilou-se ao lado de Stalin contra o bloco Trotsky/Zinoviev. Entretanto, nos famosos "Processos de Moscou" dos anos 30, Bukharin foi julgado e condenado à morte por traição, em 1938. Há uma edição brasileira do livro de Bukharin, segundo nos informa Carlos Nélson Coutinho: BUKHARIN, N. Tratado do materialismo histórico. Rio de Janeiro: Laemmert, 1970. GRAMSCI, A. Cadernos do cárcere. Introdução ao estudo da filosofia. A filosofia de Benedetto Croce. Trad. Carlos Nelson Coutinho. Rio de Janeiro: Civilização Brasileira, 1999, v.1, p.460, nota 18.

${ }^{28}$ Como leitor de Maquiavel, Gramsci incorporou como poucos o binômio fortuna e virtú, ou seja, a maneira de agir com talento e competência de forma calculada e pensada ( $v$ ir$t u ́$ ), aproveitando as condições da realidade existente (fortuna). Vejam-se sobre o assunto, DIAS, E. F. O eterno fascínio do florentino. Para uma leitura de Maquiavel. Campinas: IFCH/Unicamp, 1999, (Textos didáticos, n.37), além, é claro, de MAQUIAVEL, N. O príncipe (várias edições).

${ }^{29}$ A esse respeito, ver MONDAINI, M. Gramsci e a 'subida ao sótão’ da filosofia da práxis. In: www.gramsci.org.br.

30 "A relação entre os intelectuais e o mundo da produção não é imediata, como ocorre no caso dos grupos sociais fundamentais, mas é 'mediatizada', em diversos graus, por todo o tecido social, pelo conjunto das superestruturas, do qual os intelectuais são precisamente os 'funcionários'. Seria possível medir a 'organicidade' dos diversos estratos intelectuais, sua conexão mais ou menos estreita com um grupo social fundamental, fixando uma gradação das funções e das superestruturas de baixo para cima (da base estrutural para o alto)." GRAMSCI, A. Cadernos do cárcere. Os intelectuais. O princípio educativo. Jornalismo. Rio de Janeiro: Civilização Brasileira, 2000, v.3, p.20.

${ }^{31}$ GRAMSCI, A., op. cit., v.1, p.196-7.

${ }^{32}$ Vale a pena acompanhar a citação completa de Gramsci: "A pretensão (apresentada como postulado essencial do materialismo histórico) de apresentar e expor qualquer flutuação da política e da ideologia como uma expressão imediata da infra-estrutura deve ser combatida, teoricamente, como um infantilismo primitivo, ou deve ser combatida, praticamente, com o testemunho autêntico de Marx, escritor de obras políticas e históricas concretas ... Poder-se-á observar quantas cautelas reais Marx introduziu em suas investigações concretas, cautelas que não poderiam encontrar lugar nas obras gerais”. Ibidem, p.238.

${ }^{33}$ DOSSE, F. História do estruturalismo. 1. O campo do signo, 1945/1966. Trad. Álvaro Cabral. São Paulo: Ensaio, Campinas, Ed. Unicamp, 1993, v.1, p.23.

${ }^{34}$ Ibidem, p.24.

${ }^{35}$ SARTRE, J.-P. Crítica da razão dialética: precedido por Questões de método. Trad. Guilherme João de Freitas Teixeira. Rio de Janeiro: DP\&A, 2002, p.30. Grifos meus.

${ }^{36}$ Ibidem, p.19-21.

${ }^{37}$ Ibidem, p.21. 
${ }^{38}$ Há uma grande diferença entre as noções de que a consciência seja "reflexo" ou "produto" do ser social. Enquanto "reflexo" ela aparece automática e imediatamente sem mediações; já como "produto", há o processo de elaboração no qual o "ser social" opera as mediações de sua existência objetiva, transformando-a em "consciência", produto subjetivo de um ato mediato individual ou coletivo. Aqui, vale a citação de Sartre, também lembrada por Emília Viotti: "Valery é um intelectual pequeno-burguês, eis o que não suscita qualquer dúvida. Mas nem todo intelectual pequeno-burguês é Valery”. Ibidem, p.54.

${ }^{39}$ Ibidem, p.29.

${ }^{40}$ Ibidem, p.34.

${ }^{41}$ Ibidem, p.35-45. Contra o apriorismo Sartre discorre: "É necessário simplesmente rejeitar o apriorismo: somente a análise sem preconceitos do objeto histórico poderá, em cada caso, determinar se a ação ou a obra refletem os motivos superestruturais de grupos ou indivíduos formados por certos condicionamentos de base, ou se podem ser explicados apenas por referência imediata às contradições econômicas e aos conflitos de interesses materiais". Ibidem, p.45.

${ }^{42}$ Nesse ponto Sartre analisa o caso de Gustave Flaubert, pai do realismo e autor do famoso romance Madame Bovary, para mostrar o quanto as mediações, que podem ser encontradas na "particularidade de uma história" que começa com a infância e prossegue na idade adulta em cada grupo de pertencimento em que o indivíduo ingressa, influenciaram na formação da personalidade literária e no posicionamento político-social de um autor. Ibidem, p.49-58. Emília Viotti chamou a atenção para o papel pioneiro exercido por Sartre que reivindicava uma história da sexualidade e da infância, além da crítica por ele feita às noções "essencialistas", "funcionalistas" e "estáticas”. No entanto, "A historiografia dos nossos dias leva em conta os defeitos assinalados por Sartre, se bem que ao tentar evitá-los não seguiu os caminhos por ele indicados". COSTA, E. V. da., op. cit., p.19-20.

${ }^{43}$ Segundo Viotti, a obra de Raymond Aron, adversário político de Sartre, tinha sido bastante desprezada pela intelectualidade francesa da década de 1960, pela sua falta de profundidade. Op. cit., p.18. A opinião de Viotti talvez não faça justiça à aceitação que Aron teve ao menos entre os liberais que o utilizavam justamente para combater o marxismo.

${ }^{44}$ VEYNE, P., op. cit., p.151-81. O texto, "Foucault revoluciona a história”, foi colocado em apêndice à edição francesa do referido livro em 1969.

${ }^{45}$ Sobre as relações de Foucault e dos estruturalistas franceses com o PCF, veja-se o livro de DOSSE, op. cit., passim. Como pensador bastante influente entre nós, Foucault teve boa parte de sua obra traduzida para o português.

${ }^{46}$ Como se sabe, o ano de 1956 foi bastante emblemático para a história da esquerda e dos partidos comunistas pelo mundo. Com a divulgação dos Relatórios Secretos do líder soviético Nikita Kruschev, no XX Congresso do Partido Comunista da União Soviética, o mundo veio a conhecer em detalhes a profundidade da ditadura burocrática de Joseph Stalin, que havia assassinado milhões de camponeses, trabalhadores e quase toda a velha 
guarda do Partido Bolchevique que fizera a Revolução de 1917. Quase todos haviam sido condenados sob a acusação de colaborarem com a contra-revolução.

${ }^{47}$ Apesar das defecções no PCGB, nem todos os historiadores da New Left Review debandaram em 1956. Vejam-se os casos de Eric Hobsbawm e Maurice Dobb, que saíram do PC nos anos seguintes.

${ }^{48}$ THOMPSON, E. P. A miséria da teoria ou um planetário de erros: uma crítica ao pensamento de Althusser. Trad. Waltensir Dutra. Rio de Janeiro: Zahar, 1981.

${ }^{49}$ Sobre essas heranças, especialmente a de Gramsci e Sartre, Thompson expressa respeito e consideração, muito embora não assuma inteiramente nenhuma delas. Ibidem, passim.

${ }^{50}$ Curiosamente, apesar de sua grande reputação acadêmica, Thompson nunca foi um "professor universitário", preferindo lecionar para trabalhadores em cursos de formação variados. Sobre o assunto, ver: FORTES, A., NEGRO, A. L., FONTES, P. Peculiaridades de E. P. Thompson. In: As peculiaridades dos ingleses e outros artigos. Trad. e org. Antonio Luigi Negro e Sérgio Silva. Campinas: Ed. Unicamp, 2001, p.21-57.

${ }^{51}$ THOMPSON, E. P., op. cit., p.12.

${ }^{52} \mathrm{O}$ dialogismo do pensamento de Thompson pode ser percebido na citação completa: "A investigação da história como processo, como sucessão de acontecimentos ou 'desordem racional', acarreta noções de causação, de contradição, de mediação e da organização (por vezes estruturação) sistemática da vida social, política, econômica e intelectual. Essas elaboradas noções 'pertencem' à teoria histórica, são refinadas dentro dos procedimentos dessa teoria, são pensadas dentro do pensamento. Mas não é verdade que a teoria pertença apenas à esfera da teoria. Toda noção, ou conceito, surge de engajamentos empíricos e por mais abstratos que sejam os procedimentos de sua auto-interrogação, esta deve ser remetida a um compromisso com as propriedades determinadas da evidência, e defender seus argumentos ante juízes vigilantes no 'tribunal de recursos' da história. Trata-se, num sentido bastante crítico, novamente de uma questão de diálogo. Na medida em que uma tese (o conceito, ou hipótese) é posta em relação com suas antíteses (determinação objetiva não teórica) e disso resulta uma síntese (conhecimento histórico), temos o que poderíamos chamar de dialética do conhecimento histórico". Ibidem, p.53-4.

${ }^{53}$ Sobre o assunto, ver a magistral exposição de Carlo Ginzburg, para quem a história não seria um conhecimento, ou uma ciência, de tipo galileano, e sim, uma espécie de conhecimento indiciário. GINZBURG, C. Sinais: Raízes de um paradigma indiciário. In: Mitos, emblemas e sinais. Morfologia e história. Trad. Francisco Carotti. 2.ed. São Paulo: Companhia das Letras, 1991, p.143-79.

${ }^{54}$ THOMPSON, op. cit., p.48, 57.

${ }^{55}$ THOMPSON. As peculiaridades dos ingleses, in op. cit., p.75-189. Ver também a propósito da historiografia inglesa: HOBSBAWM, E. A história britânica e os Annales: um co- 
mentário. In: Sobre história. Ensaios. Trad. Cid Knipel Moreira. São Paulo: Companhia das Letras, 1998, p.193-200.

${ }^{56}$ Ver a esse respeito o capítulo d'A miséria da teoria, Da Economia Política à Origem das Espécies, em que Thompson observa que Marx terminou sendo tragado pelo "remoinho estrutural" da Economia Política ao promover a sua crítica. Ibidem, p.66-82.

${ }^{57}$ Ibidem, p.57. A concepção de classe de Thompson, como se sabe, aparece plenamente desenvolvida na sua obra A formação da classe operária inglesa. Trad. Denise Bottman. 2.ed. Rio de Janeiro: Paz e Terra, 1987, 3v.

${ }^{58}$ BOTTOMORE, op. cit., p.101.

${ }^{59}$ GINZBURG, C. Relações de força. História, retórica, prova. Trad. Jônatas Batista Neto. São Paulo: Companhia das Letras, 2002, p.14.

${ }^{60}$ THOMPSON, op. cit., p.9-10.

${ }^{61}$ Ibidem, p.47-62.

${ }^{62}$ Sobre as trocas entre a história e a antropologia, Ginzburg observa: "Aos historiadores ofereceu a antropologia não só uma série de temas largamente descurados no passado desde as relações de parentesco até a cultura material, desde os rituais simbólicos até a magia - mas qualquer coisa de muito mais importante: um quadro conceitual de referência, do qual se começam a entrever os contornos". GINZBURG, C. O nome e o como. Troca desigual e mercado historiográfico. In: A micro-história e outros ensaios. Trad. Antonio Narino. Lisboa: Difel, Rio de Janeiro: Bertrand Brasil, 1989, p.172-3.

${ }^{63} \mathrm{O}$ exemplo de Paul Veyne, que dedicou o texto "Foucault revoluciona a história" ao filósofo francês, é apenas um dos primeiros. O historiador francês, que passou boa parte de sua vida estudando a antiguidade clássica, optou por discutir o ofício do historiador dedicando-se pioneiramente a "desconstruir" as teorias e metodologias vigentes, inclusive as que moveram a sua própria obra. Mas os exemplos podiam ser multiplicados, com Michel de Certeau, Roger Chartier e Hayden White, apenas para ficar naqueles que se empenharam firmemente em desconstruir a história a partir de dentro.

${ }^{64}$ Ginzburg vê com desconfiança as trocas entre a história e a lingüística. Sobre o assunto, ver: Relações de força, passim.

${ }^{65}$ HOBSBAWM, E. Sobre história, cit., p.8.

${ }^{66}$ Ibidem, p. 10.

${ }^{67}$ GINZBURG, C. Relações de força, p.61. A citação completa é: “A redução, hoje em voga, da história à retórica, não pode ser repelida sustentando-se que a relação entre uma e outra sempre foi fraca e pouco relevante. Na minha opinião, essa redução pode e deve ser rechaçada pela reavaliação da riqueza intelectual da tradição que remonta a Aristóteles e à sua tese central: as provas, longe de serem incompatíveis com a retórica, constituem o seu núcleo fundamental". Ibidem, p.63. 
${ }^{68}$ Por questões de espaço, dispensarei a referência completa a tais textos.

${ }^{69}$ COSTA, E. V. da. Coroas de glória, lágrimas de sangue. A rebelião dos escravos de Demerara em 1823. Trad. Anna Olga de Barros Barreto. São Paulo: Companhia das Letras, 1998.

${ }^{70}$ Veja-se, apenas como exemplo, o excelente livro de HARDMAN, F. F. Nem pátria, nem patrão. Memória operária, cultura e literatura no Brasil. 3.ed. revista e ampliada. São Paulo: Ed. Unesp, 2002. Além desse texto, inúmeros estudiosos, integrantes do GT "Mundos do Trabalho" da Associação Nacional de História (ANPUH), têm produzido trabalhos fundamentais que, pela envergadura, seria dispendioso citar, senão apenas através de alguns balanços recentes: BATALHA, C. H. M. A historiografia da classe operária no Brasil: trajetórias e tendências. In: FREITAS, M. C. (Org.) Historiografia brasileira em perspectiva. São Paulo: Contexto, 1998, p.145-58; História do trabalho: um olhar sobre os anos 1990. História. São Paulo, n.21, p.73-87, 2002; PETERSEN, S. R. F. Cruzando fronteiras: as pesquisas regionais e a história operária brasileira. In: ARAÚJO, A. M. C. Trabalho, cultura e cidadania: um balanço da história social brasileira. São Paulo: Scritta, 1997, p.85-103.

${ }^{71}$ Somente para citar um ramo dessa historiografia, convém mencionar os trabalhos oriundos do GT História dos Partidos e Movimentos de Esquerda. Membros desse GT, inicialmente na ANPOCS, hoje na ANPUH, estarão concluindo ainda em 2005 a publicação da coletânea História do marxismo no Brasil, em seis volumes (Ed. Unicamp, 1995-2004 - o primeiro volume, que em 2004 ganhou uma segunda edição revista e ampliada, saiu pela Paz e Terra em 1991). É também neste segmento historiográfico que muitos trabalhos estão revisitando a história do principal partido da esquerda brasileira, o PCB, como é o caso do recente livro de KAREPOVS, D. Luta subterrânea. O PCB em 1937-1938. São Paulo: Hucitec, Unesp, 2003.

${ }^{72}$ Segundo Rémond, "De fato, a renovação da história política foi grandemente estimulada pelo contato com outras ciências sociais e pelas trocas com outras disciplinas. É uma verdade geral a utilidade, para todo ramo do saber, de abrir-se a outros e acolher contribuições externas, mas o objeto da história política, sendo por sua natureza interdisciplinar, torna isso uma necessidade mais imperativa que em outros casos. É impossível para a história política praticar o isolamento: ciência-encruzilhada, a pluridisciplinaridade é para ela como o ar que ela precisa para respirar". Cf. RÉMOND, R. (Org.) Por uma história política. Trad. Dora Rocha. Rio de Janeiro: Ed. UFRJ, Ed. FGV, 1996, p.29.

${ }^{73}$ FERREIRA, J. (Org.) O populismo e sua história. Debate e crítica. Rio de Janeiro: Civilização Brasileira, 2001. Por ser uma coletânea de artigos de autores distintos, obviamente as contribuições apresentam variações de interpretação e opções teóricas diferenciadas. Entretanto, se não há a possibilidade de concordarmos em bloco com todos os textos, não podemos negar o mérito de importantes contribuições.

${ }^{74}$ GRAMSCI, op. cit., v.2, p.267. 